\title{
ATIC/ALK Fusion Protein
}

National Cancer Institute

\section{Source}

National Cancer Institute. ATICIALK Fusion Protein. NCI Thesaurus. Code C101047.

A fusion protein encoded by the ATIC/ALK fusion gene. This protein is comprised of the IMPCH and the dimerization domains of the bifunctional purine biosynthesis protein PURH fused to the cytoplasmic domain of the ALK tyrosine kinase receptor protein, including the tyrosine kinase domain. 